\title{
QUESTÃO SOCIOAMBIENTAL
}

Nos próximos anos, a discussão sobre temas do meio ambiente continuará produzindo controvérsia. A comunidade científica e os governos estão longe de uma posição consensual. Há mesmo quem questione se as variações no clima refletem uma tendência ou consistem em mera oscilação; e se seriam ou não causadas pela intervenção humana. Sylmara Lopes Francelino Gonçalves-Dias, professora da PUC-SP, selecionou obras que levam a olhar o homem e a natureza de maneira indissociável, e fazem refletir sobre a necessidade de soluções integradas para as questões ambientais.

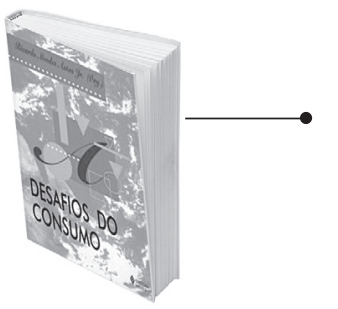

DESAFIOS DO CONSUMO. Ladislau Dowbor, Hélio Silva e Ricardo Mendes Antas Jr. (Orgs.). Petrópolis, RJ: Vozes, 2007.344 p.

A coletânea reúne visões sobre o consumo como um poderoso estruturador das sociedades atuais. São discutidos temas como os impactos ambientais do consumo; o efeito do consumismo obsessivo sobre o bem-estar das pessoas; as mudanças culturais em curso; e problemas setoriais diferenciados, como, por exemplo, a proteção das reservas de água doce.

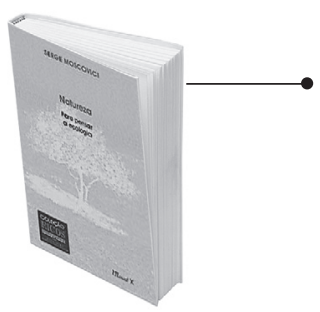

NATUREZA: para pensar a ecologia. Serge Moscovici. Rio de Janeiro: Mauad X, 2007. 256 p.

A obra oferece uma retrospectiva do movimento ecológico europeu e das questões epistemológicas que se encontram em suas raízes. Como militante e pensador das causas ambientais, o psicossociólogo Serge Moscovici propõe uma nova visão do homem, da natureza e da cultura, a qual chama de naturalismo subversivo. Pensar a natureza sob essa perspectiva leva a reconsiderações sobre a fragilidade e a viabilidade da presença humana em harmonia com a natureza.

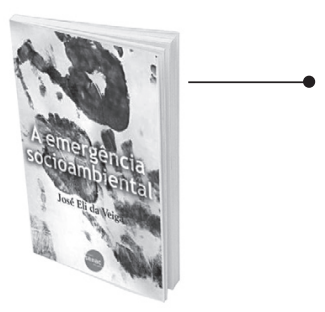

A EMERGÊNCIA SOCIOAMBIENTAL. José Eli da Veiga. São Paulo: Senac, 2007. 138 p.

O termo "socioambiental", cada vez mais utilizado em diversos setores, seria apenas mais um neologismo que remete a um conceito abstrato? Não para o autor, que vê na unificação desse termo um verdadeiro movimento político e o surgimento de uma nova relação entre natureza e cultura. Veiga define "socioambiental" como uma "unidade de contrários" e defende a necessidade de alterar os estilos materiais do crescimento - e do consumo - para que se alcance a sustentabilidade.

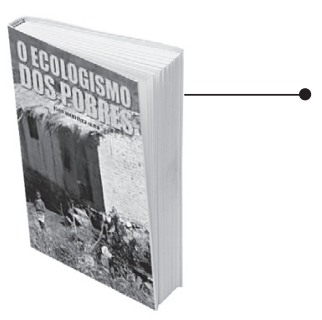

O ECOLOGISMO DOS POBRES. Joan Martínez Alier. São Paulo: Contexto, 2007. 384 p.

O autor investiga as relações entre dois campos de estudo emergentes: ecologia política e economia ecológica. Além disso, traça um panorama das tensões relativas ao acesso a recursos naturais, e derivadas da relação entre progresso econômico e uso do meio ambiente.

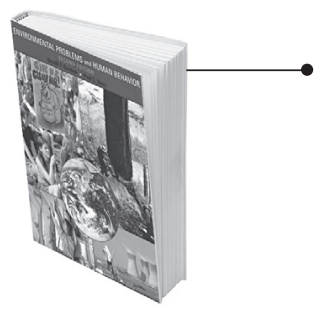

ENVIRONMENTAL PROBLEMS AND HUMAN BEHAVIOR. Gerald Gardner e Paul Stern. 2. ed. Boston: Pearson Custom Publishing, 2002. $371 \mathrm{p}$.

O livro examina as dimensões comportamentais dos problemas ambientais globais e regionais. Busca responder a questões como: Por que as pessoas persistem em se comportar de forma destrutiva em relação ao meio ambiente? Como esses comportamentos podem ser mudados? Os seres humanos e suas instituições são capazes de interagir de forma bem-sucedida com sistemas ambientais complexos? Nas respostas a essas questões, os autores apresentam uma síntese de resultados de pesquisas e teorias originárias da psicologia, ciências sociais e outras disciplinas. 